\title{
Board of directors, performance and firm value in Brazilian listed state-owned enterprises
}

\author{
Carolina Coletta ${ }^{\dagger}$ \\ Roberto Arruda de Souza Lima
}

\begin{abstract}
This paper investigates the relationship between the board of directors' structure and firm performance and the value of Brazilian listed state-owned enterprises (SOEs), from 2002 to 2017, totaling 327 observations using an unbalanced panel data with fixed and random effects regressions. The evolution of corporate governance practices adopted by the boards is presented for this period, using a Board Structure Index (BSI). The results indicate a significant positive relation between the board's structure and firm performance, measured by ROE and ROA, and firm value, measured by Tobin's $q$. These findings are consistent with corporate governance literature, in the sense that the board's role of monitoring management reduces agency conflicts. The results also show an improvement in adopting corporate governance practice on Brazilian SOEs' boards over the last decade.
\end{abstract}

Keywords: Corporate governance; Board of directors; State-owned enterprises; Corporate governance index

JEL Code: G34, G38.

\section{Introduction}

Corporate governance mechanisms are responsible for reducing agency conflicts and shareholders' expropriation (Shleifer and Vishny; 1994). Several studies in emerging markets have demonstrated that firm value and performance are associated with firm-level corporate governance. However, there is a lack of studies on which specific aspects of corporate governance (such as board attributes) are associated with firm value (Black et al.; 2020). Board attributes, such as independence, can lead to higher firm value and performance by reducing agency conflicts (Bhat et al.; 2018). Therefore, it is important to understand the relation between corporate governance mechanisms and performance to develop proper corporate and public policies (Kao et al.; 2019).

In the context of state-owned enterprises (SOEs), boards must develop, monitor and communicate internal controls, ethics codes and other measures to prevent fraud and corruption. The State must allow boards to exercise their

Submitted on December 19, 2019. Revised on June 1st, 2020. Accepted on June 2nd, 2020. Published online in July 2020. Editor in charge: Andrea Minardi.

†Sao Paulo School of Business - FGV, Brazil: coletta. carolina@gmail.com

${ }^{\ddagger}$ University of Sao Paulo, Brazil: raslima@usp. br 
responsibilities and respect their independence (OECD; 2015). In addition to agency theory's principal-agent relation, the principal-principal relation must be considered for SOEs (Chen et al.; 2019). In principal-principal relations, conflicts emerge from the interaction between SOEs and governments. Governments can extract financial benefits from these firms, expropriating other investors' capital. Conflicts surrounding the principal-principal relation are more likely when the government is the majority shareholder because it can use its voting power and control to obtain political benefits (Lazzarini and Musacchio; 2018).

SOEs, undoubtedly, operate in a context prone to political interference. Thus, decisions can be made to benefit political interests, rather than the business of the firm (Shleifer and Vishny; 1994). Governments can appoint board members according to their interests, with little incentive to properly monitor managers in order to reduce agency conflicts (Musacchio et al.; 2015).

In addition to their key monitoring role, the board's leadership in SOEs is critical to develop the firm's goals and strategies to achieve high corporate performance (Simpson; 2014). Considering that board members' decisions can impact the firm's stability, the quality of the board's contributions and actions depends on how such a board is formed (Mathew et al.; 2016). Bhat et al. (2018) argue that agency conflicts are minimized when board members are independent, which leads to better corporate performance. It is not unusual for board members in SOEs to be nominated by members of government, which results in inexperienced, influenced directors who negatively impact firm performance by generating inefficiencies for such firms (Thompson et al.; 2019).

Corporate governance literature presents few empirical studies regarding board of director's composition in SOEs (Menozzi et al.; 2012) and how the relationship between business and political decisions within the board occurs in such firms (Apriliyanti and Randøy; 2019). The limited number of empirical studies on corporate governance of SOEs in emerging markets is also noteworthy (Thompson et al.; 2019). Moreover, due to the importance and central role played by SOEs in developing countries, it is imperative to understand the factors that drive the performance of these firms (Mbo and Adjasi; 2017).

Considering the concerns presented in this section, the following research question is proposed by this paper: Does the adoption of good corporate governance practices by the board of directors result in higher performance and firm value for Brazilian listed SOEs, despite the conflicts arising from the principal-principal relation? Thus, this paper investigates the relationship between the structure of the board of directors and firm value and performance 
of Brazilian listed SOEs. In addition, the evolution of corporate governance practices adopted by boards of such firms, from 2002 to 2017, is presented.

\section{Literature review}

Boards of directors are considered the most important firm-level corporate governance factor (Khongmalai and Distanont; 2017). In the agency theory perspective, boards play an important role in preventing decisions that are not aligned with the residual claimants' interests (Fama and Jensen; 1983). Boards with improved structure and a higher proportion of independent members can exercise better monitoring, and thereby reduce agency conflicts (Bhat et al.; 2018). Black et al. (2020) explain that an improvement in board structure, aligned with improved disclosure, can have an impact on a firm's market value since expected cash flows to minority shareholders are increased.

In the context of SOEs, an important interaction arises in addition to agency theory's traditional principal-agent relation: the principal-principal conflict perspective (Chen et al.; 2019). In hybrid SOEs, conflicts in the relationship between governments and public firms can negatively impact these firms' management and consequently, their performance. This occurs because the government attempts to extract political benefits from such firms, expropriating private investors' return on capital (Lazzarini and Musacchio; 2018). Governments can dominate the boards' behavior by directly appointing directors that suit their interests. In this way, boards can be used as political tools, since they are unlikely to defy poor decisions made by political entities (Thompson et al.; 2019). Another conflict from the principal-principal perspective is that board members can be manipulated to support political interests that do not reflect the firms' business interests, therefore, impacting their performance (Apriliyanti and Randøy; 2019).

Board leadership in SOEs is critical to ensure that the firms' objectives and strategies are developed to achieve a high firm performance (Simpson; 2014). Improving board effectiveness is extremely important for performance, regardless of business size or location (Shawtari et al.; 2017). Several empirical studies in emerging markets have demonstrated that firm value is associated with firm-level corporate governance, usually measured by countryspecific indices. Different aspects of board structure have been used to explain the relation with firm value and firm performance, based on agency theory. However, little is known about which specific aspect of corporate governance drives this association (Black et al.; 2020).

Shawtari et al. (2017) find evidence that board size is negatively related to firm performance, measured by earnings before interest and tax (EBIT), for a sample of Malaysian SOEs. For these authors, larger boards can harm firm 
performance, as communication and coordination are impaired. Their results also evidence a negative relation between the duality of positions - CEO and chairman of the board being the same person - and firm performance, due to agency conflicts.

Considering board independence and firm performance, Liu et al. (2015) investigate this relation on the performance of Chinese listed firms, measured by return on equity (ROE) and return on assets (ROA). They find a positive relation, especially for firms controlled by the government. Similarly, Kao et al. (2019) conclude that board independence has a positive effect on performance indicators such as ROA and ROE, for a sample of Taiwanese listed firms.

Khongmalai and Distanont (2017) analyze the relation between corporate governance practices and performance of SOEs in Thailand and argue that the board, on its own, is not capable of leading SOEs to positive performance. In order to be effective, boards must force firms to develop effective management systems and controls, such as internal audits, internal controls, risk management, strategic management of human resources and information technology management. Therefore, corporate governance must also be incorporated at the operational level to be effectively implemented in SOEs, according to the authors.

In the agency theory perspective, a large body of research has investigated the relation of different measures of corporate governance and firm value, mostly using Tobin's $q$ as a proxy (Ararat et al.; 2017). In this vein, Kao et al. (2019) conclude that board independence has a positive effect on firm value of Taiwanese firms, proxied by Tobin's $q$. According to a study by Fauver et al. (2017), considering data on board reforms in 41 countries, reforms regarding board independence lead to an increase in firm value, also measured by Tobin's $q$.

In addition to members' independence, Bhat et al. (2018) investigate board attributes such as size and frequency of meetings and their impact on Tobin's $q$ for a sample of Pakistani firms. Regarding SOEs, the authors find evidence that all the attributes considered are positively related to Tobin's $q$, although only board independence presents statistical significance. On the other hand, for private firms, board independence is the only attribute positively related to Tobin's $q$. These findings are explained considering that independent board members reduce agency conflicts and protect shareholders' interests, which leads to higher performance.

Following such evidence, given the political manipulation context of SOEs, Apriliyanti and Randøy (2019) point out the importance of independent directors, since their decision making is more appropriate to SOEs' business goals, 
considering national interests as well as shareholders' interests. These findings are consistent with the argument proposed by Musacchio et al. (2015) regarding the low incentive that board members appointed by the government have to monitor managers and to take business-oriented decisions.

Monitoring is less effective when board members declared as independents have hidden underlying political connections, leading to destruction of firm value (Shi et al.; 2018). Thompson et al. (2019) find that the recruitment and selection of board members in SOEs in Barbados were motivated by political affiliation, compromising the independence of the boards. In this situation, there lack objective criteria for appointing board members and their mandate is determined based on political government changes. The consequence is the presence of inexperienced members on the board, who negatively impact firm performance by generating inefficiencies for the SOEs (Thompson et al.; 2019).

Finally, recent corporate governance literature highlights that board structure may be endogenous with respect to firm performance. In this sense, a poorly-structured board may be the fittest solution to the constrained optimization problem faced by the firm (Adams et al.; 2010). Hermalin and Weisbach (1988) provide an example of how past performance may influence the bargaining process within the firm and, consequently, the board structure regarding independent directors, which implies the endogenous aspect of board composition. The authors explain that when a firm performs poorly, a concern about poor management and thus the need for better monitoring arises. Therefore, the CEO is pressured to accept a larger proportion of outside directors on the board.

Given the evidence from the empirical studies discussed in this section, the following hypotheses are formulated:

$\mathrm{H}_{1}$ : corporate governance best practices implemented on the board of directors result in higher firm performance for Brazilian listed SOEs.

$\mathrm{H}_{2}$ : corporate governance best practices implemented on the board of directors result in higher firm value for Brazilian listed SOEs.

\section{Methodological procedures}

\subsection{Population and sample}

The research population is composed of 30 SOEs listed in Brazil throughout 2017. From this set, firms registered in the CVM category B and those that presented negative value in the shareholders' equity account were excluded, as it would not be possible to calculate the ROE indicator. Therefore, 
the non-probabilistic sample resulted in an unbalanced panel data of 22 listed SOEs, from 2002 to 2017, resulting in 327 firm-year observations. The determination of the year 2002 is based on the beginning of a greater discussion on corporate governance, due to the first listing on the "New Market," a special listing segment in B3, and the Sarbanes-Oxley Act passing in the same year.

\subsection{Variables and data collection}

Considering the purpose of the paper of investigating the relationship between the board of directors' structure and firm value and performance of Brazilian listed SOEs, the definition of such variables is required. The board structure index (BSI) is used to measure corporate governance practices adopted by the boards. To measure firm performance, the indicators return on equity (ROE) and return on total assets (ROA) were selected, while Tobin's $q$ is a proxy for firm value. Control variables include leverage, firm size, stock liquidity, and a dummy variable for SOEs listed in the Level 2 and New Market, the special listing segment in B3.

\section{Independent variable}

In order to measure corporate governance practices implemented in Brazilian SOEs' boards, a board structure index (BSI) was created, similarly to Paiva et al. (2015). BSI is composed of 7 questions regarding practices adopted by the board: the duality of positions, size, percentage of external directors, provision of independent members, reservation of seats for members of the public administration, the unified mandate of up to 2 years, and the existence of board performance evaluation mechanisms.

The board index was developed considering the corporate governance index (IGOV) by Silveira et al. (2005), with additional information from Silva and Leal (2005), Assunção et al. (2017), IBGC (2015, 2017); B3 (2017) and the Secretary of Coordination and Governance of State Enterprises (SEST; 2018). The result is the Board Structure Index (BSI) presented in Table 1.

BSI is composed of objective binary questions, whose answers are obtained from secondary and publicly available data. For each positive answer to the questions, one point is added to the index, so that the index ranges from 0 to 7 points for each firm. Regarding question number 5, the firm whose bylaws establish such seat reservations does not score on this matter, since it represents political interference. This may harm the board's independence and compromise corporate governance quality (IBGC; 2017). If the answer to the referred question is positive, the firm receives a zero score on this question. 
Table 1

Board Structure Index (BSI)

\begin{tabular}{|c|c|c|}
\hline item & question & theoretical basis \\
\hline 1 & $\begin{array}{l}\text { Are the CEO and chairman of the board } \\
\text { different persons? }\end{array}$ & $\begin{array}{l}\text { Silveira et al. (2005), Silva and } \\
\text { Leal (2005), IBGC (2015), } \\
\text { Paiva et al. (2015). }\end{array}$ \\
\hline 2 & $\begin{array}{l}\text { Is the board composed of } 5 \text { to } 11 \mathrm{mem} \text { - } \\
\text { bers? }\end{array}$ & $\begin{array}{l}\text { Silveira et al. (2005), Silva } \\
\text { and Leal (2005), Paiva et al. } \\
\text { (2015), IBGC (2015) }\end{array}$ \\
\hline 3 & $\begin{array}{l}\text { Is more than } 80 \% \text { of the board of direc- } \\
\text { tors composed of external directors? }\end{array}$ & Silveira et al. (2005) \\
\hline 4 & $\begin{array}{l}\text { Do bylaws formally provide for the par- } \\
\text { ticipation of independent members on } \\
\text { the board of directors? }\end{array}$ & $\begin{array}{l}\text { IBGC (2017); B3 (2017); } \\
\text { SEST (2018) }\end{array}$ \\
\hline 5 & $\begin{array}{l}\text { Do bylaws establish explicit reservation } \\
\text { of board seats for occupants of specific } \\
\text { positions in the direct public administra- } \\
\text { tion of controller's federative entity? }\end{array}$ & $\begin{array}{l}\text { IBGC (2017); B3 (2017); } \\
\text { SEST (2018) }\end{array}$ \\
\hline 6 & $\begin{array}{l}\text { Does the board have a unified mandate of } \\
\text { up to } 2 \text { years? }\end{array}$ & $\begin{array}{l}\text { Silveira et al. (2005), Silva } \\
\text { and Leal (2005), Paiva et al. } \\
(2015) \text {, IBGC (2015) }\end{array}$ \\
\hline 7 & $\begin{array}{l}\text { Are there performance evaluation mech- } \\
\text { anisms of board members? }\end{array}$ & $\begin{array}{l}\text { Assunção et al. (2017); IBGC } \\
\text { (2015) }\end{array}$ \\
\hline
\end{tabular}

The information needed to compose the BSI was hand collected through bylaws and the Reference Forms (FR) from 2009 to 2017, and the Annual Informative (IAN) for 2002 to 2008. Those are mandatory documents made available by the Brazilian Securities Exchange Commission (CVM). Control variables - except for the N2NM variable, collected on the B3 website were collected from Economatica database. The standard FR and IAN items consulted to answer each index question are presented in Table 2.

\section{Dependent variables}

As Kao et al. (2019) state, studies often analyze only one indicator of firm performance. We follow these authors and consider accounting and market measures as dependent variables: Tobin's $q$, return on equity (ROE) and return on assets (ROA).

Tobin's $q$ is used as the dependent variable to measure firm value. Tobin's $q$ is often considered as an outcome variable in empirical financial research as a proxy for firm value (Famá and Barros; 2000) especially in corporate governance studies (Ararat et al.; 2017).

a) Tobin's $q$ : it is defined as the sum of the market value of stocks and the market value of debt, divided by asset replacement costs (Silveira et al.; 
Table 2

Source of data collection for the Board Structure Index

\begin{tabular}{|c|c|c|c|}
\hline \multicolumn{2}{|r|}{ questions } & \multicolumn{2}{|c|}{ data source } \\
\hline & board structure index & $\begin{array}{c}\text { reference forms } \\
2017-2009\end{array}$ & $\begin{array}{l}\text { annual informative } \\
\text { (IAN) }\end{array}$ \\
\hline 1 & $\begin{array}{l}\text { Are the CEO and chairman of } \\
\text { the board different persons? }\end{array}$ & item $12.5 / 6$ - FR & group 02 - IAN \\
\hline 2 & $\begin{array}{l}\text { Is the board composed of } 5 \text { to } \\
11 \text { members? }\end{array}$ & item $12.5 / 6$ - FR & group 02 - IAN \\
\hline 3 & $\begin{array}{l}\text { Is more than } 80 \% \text { of the board } \\
\text { of directors composed of ex- } \\
\text { ternal directors? }\end{array}$ & item $12.5 / 6-F R$ & group 02 - IAN \\
\hline 4 & $\begin{array}{l}\text { Do bylaws formally provide } \\
\text { for the participation of inde- } \\
\text { pendent members on the board } \\
\text { of directors? }\end{array}$ & bylaws (CVM) & group 18 - IAN \\
\hline 5 & $\begin{array}{l}\text { Do bylaws establish explicit } \\
\text { reservation of board seats for } \\
\text { occupants of specific positions } \\
\text { in the direct public administra- } \\
\text { tion of controller's federative } \\
\text { entity? }\end{array}$ & bylaws (CVM) & group 18 - IAN \\
\hline 6 & $\begin{array}{l}\text { Does the board have a unified } \\
\text { mandate of up to } 2 \text { years? }\end{array}$ & item $12.5 / 6-F R$ & group 02 - IAN \\
\hline 7 & $\begin{array}{l}\text { Are there performance eval- } \\
\text { uation mechanisms of board } \\
\text { members? }\end{array}$ & item $12.1-\mathrm{FR}$ & group 20 - IAN \\
\hline
\end{tabular}

2005). Chung and Pruitt (1994) propose a simplified approximation of Tobin's $q$ :

$$
\text { Tobin's } q=\frac{\text { MVCS }+ \text { MVPS }+ \text { DEBT }}{\text { TA }},
$$

where

- $\mathrm{MVCS}=$ market value of common shares;

- MVPS = market value of preferred shares;

- DEBT $=$ book value of total debt; and

- $\mathrm{TA}=$ book value of total assets.

Two financial indicators are used as proxies for SOEs' firm performance: ROE and ROA. Investigating the effects of board structure on performance can help to understand if profitability is a channel for the 
association of corporate governance measures and firm value, as conducted by Black et al. (2020). Therefore, we employ the following outcomes variables.

b) ROE measures the return obtained by the firm on the past investments on equity (Berk and DeMarzo; 2017). Thus, ROE can be defined as:

$$
\mathrm{ROE}=\frac{\text { net income }}{\text { book value of equity }}
$$

c) ROA measures the effectiveness in profit generation from total assets (Gitman; 2004). Thus, ROA is defined as:

$$
\mathrm{ROA}=\frac{\text { net income }}{\text { book value of assets }}
$$

\section{Control variables}

The following control variables are considered due to the possibility of influence on the dependent variables: leverage (LEV), firm size (SIZE), special segment listing (N2NM) and stock liquidity indicator (LIQ).

a) Leverage (LEV): defined as the total debt divided by the book value of total assets (Gitman; 2004):

$$
\mathrm{LEV}=\frac{\text { total debt }}{\text { book value of assets }}
$$

Corporate finance literature presents some divergent evidence regarding the relation between leverage and firm performance. Some studies find a negative relation while others present evidence of positive or non-significant relations (Ibhagui and Olokoyo; 2018). Positive relations are based on studies by Modigliani and Miller (1958, 1963), who point to a positive correlation between leverage and stock returns, in addition to tax benefits arising from debt financing. On the other hand, high leverage can be associated with more risk, establishing a negative relation with firm value (Fama and French; 2002).

b) Firm size (SIZE): uses the natural logarithm value of total assets.

$$
\mathrm{SIZE}=\ln (\text { Assets })
$$

As pointed out by Vilhena and Camargos (2015), larger firms tend to present high levels of corporate governance and performance. However, larger firms may present more agency conflicts and less effective monitoring of management (Klapper and Love; 2004). 
c) Level 2 or New Market special listing segments (N2NM): dummy variable, which assumes value 1, if the firm is listed either on Level 2 or New Market in B3, and 0 otherwise.

d) Stock liquidity (LIQ): The percentage of stocks in circulation rises with high liquidity, leading to higher stock value and Tobin's $q$ (Lameira et al.; 2007). This variable is measured by and its indicator calculated by the Economatica database, as follows:

$$
\mathrm{LIQ}=100 \times\left(\frac{p}{P}\right) \times \sqrt{\left(\frac{n}{N}\right) \times\left(\frac{v}{V}\right)},
$$

where:

- $p=$ number of days with at least one trade of the stock;

- $P=$ total number of days in the period;

- $n=$ number of trades of the stock in the period;

- $N=$ number of trades of all stocks in the period;

- $v=$ cash volume traded of the stock in the period; and

- $V=$ cash volume traded of all stocks in the period.

Table 3 summarizes operational definitions of each variable and previous empirical studies in which they were similarly considered.

\subsection{Econometric specification}

Given the variables presented and discussed above, the following econometric model is formulated:

$\mathrm{PFV}_{i t}=\alpha+\beta_{1} \mathrm{BSI}_{i t}+\beta_{2} \mathrm{LEV}_{i t}+\beta_{3} \mathrm{SIZE}_{i t}+\beta_{4} \mathrm{~N}_{2} \mathrm{NM}_{i t}+\beta_{5} \mathrm{LIQ}_{i t}+n_{i}+\varepsilon_{i t}$,

where PFV stands for the dependent firm performance variables (ROA and ROE) and firm value variable (Tobin's $q$ ); BSI is the board structure index; LEV, SIZE, N2NM and LIQ are the control variables; $\alpha$ represents the intercept; $i$ represents the firm, and $t$ the year; $n$ represents the non-observed heterogeneity; and $\varepsilon$ represents the residual error.

Empirical research on the relation of corporate governance attributes and firm value may present endogeneity concerns, especially, the potential for reverse causation. In this case, the firm value proxy may predict the corporate governance value (Black et al.; 2020). One common approach to address this issue is to use instrumental variables, despite the difficulty in finding appropriate instruments for corporate governance variables (Kao et al.; 2019). 
Table 3

\section{Variables definitions}

\begin{tabular}{|c|c|c|}
\hline variables & operational definition & theoretical basis \\
\hline $\begin{array}{l}\text { BSI: Board } \\
\text { Structure Index } \\
\text { (independent) }\end{array}$ & 0 to 7 score index & $\begin{array}{l}\text { Silva and Leal (2005), As- } \\
\text { sunção et al. (2017), (IBGC; } \\
\text { 2015, 2017); B3 (2017) and } \\
\text { SEST (2018) }\end{array}$ \\
\hline ROA: Return on & net income & Paiva et al. (2015), Liu et al. \\
\hline Assets (dependent) & $\overline{\text { book value of assets }}$ & $\begin{array}{l}\text { (2015), Lazzarini and Musac- } \\
\text { chio (2018) }\end{array}$ \\
\hline ROE: Return on & net income & Liu et al. (2015), Vilhena and \\
\hline Equity (dependent) & $\overline{\text { book value of equity }}$ & Camargos (2015) \\
\hline $\begin{array}{l}\text { Q: Tobin's } q \\
\text { (dependent) }\end{array}$ & $\frac{\text { MVCS }+ \text { MVPS }+ \text { DEBT }}{\text { book value of assets }}$ & $\begin{array}{l}\text { Paiva et al. (2015), Fauver } \\
\text { et al. (2017), Bhat et al. } \\
\text { (2018), Kao et al. (2019). }\end{array}$ \\
\hline $\begin{array}{l}\text { LEV: Leverage } \\
\text { (control) }\end{array}$ & $\frac{\text { total debt }}{\text { book value of assets }}$ & $\begin{array}{l}\text { Paiva et al. (2015), Shawtari } \\
\text { et al. (2017), Lazzarini and } \\
\text { Musacchio (2018) }\end{array}$ \\
\hline $\begin{array}{l}\text { SIZE: Firm size } \\
\text { (control) }\end{array}$ & logarithm value of total assets & $\begin{array}{l}\text { Paiva et al. (2015), Liu et al. } \\
\text { (2015), Shawtari et al. (2017), } \\
\text { Lazzarini and Musacchio } \\
\text { (2018) }\end{array}$ \\
\hline $\begin{array}{l}\text { N2NM: Level } 2 \text { or } \\
\text { New Market listing } \\
\text { (control) }\end{array}$ & $\begin{array}{l}\text { dummy variable equals } 1 \text {, if } \\
\text { firm is listed on Level } 2 \text { or new } \\
\text { Market, and } 0 \text { otherwise }\end{array}$ & Paiva et al. (2015) \\
\hline $\begin{array}{l}\text { LIQ: Stock } \\
\text { Liquidity (control) }\end{array}$ & $\begin{array}{l}\text { annual stock liquidity, pro- } \\
\text { vided by Economatica: } \\
(100 p / P) \sqrt{(n / N) \times(v / V)}\end{array}$ & $\begin{array}{l}\text { Silveira et al. (2005), Lameira } \\
\text { et al. (2007) }\end{array}$ \\
\hline
\end{tabular}

Indeed, Black et al. (2020) find these instruments unconvincing. Considering the potential for reverse causation, there is evidence that time-varying firm attributes weakly predict corporate governance (Ararat et al.; 2017). We follow Black et al. (2020) and run regressions employing the outcome variables (Tobin's $q$, ROA and ROE) as predictors of BSI.

Statistical treatment comprises panel data regression analysis, estimated by fixed effects (FE) and random effects (RE). In governance-to-value studies (Ararat et al. 2017) panel data designs with FE or RE have often been employed to address the association between measures of corporate governance and firm value or firm performance (Black et al.; 2020; Kao et al.; 2019; Bhat et al.; 2018; Ararat et al.; 2017). It must be noted that these studies do not intend to establish a true causal relation. Although the absence of reverse causation makes it more plausible that the relation between corporate governance and firm value is causal, it cannot be established with certainty (Ararat et al.; 2017). In this sense, panel data is a suitable research design available 
in this context. Regression estimations with fixed or random effects, with standard errors clustered on firms, provide credibility that some prior studies have failed to accomplish (Black et al. 2020).

To establish the appropriate regression estimations, Chow and LM BreuschPagan tests were conducted. Their null hypotheses consider the adequacy of Pooled Ordinary Least Squares (POLS) instead of FE and RE, respectively. Both tests presented a p-value of 0.000 for the three dependent variables, rejecting their null hypotheses. Next, the Hausman test was conducted. It revealed the adequacy of RE for Tobin's $q(\mathrm{p}$-value $=0.1087)$ and ROA (pvalue $=0.3207)$ as dependent variables - and FE for ROE $(p$-value $=0.0025)$ as a dependent variable. Data were treated for outliers through the winsor tool in Stata at the 1\% and 99\% level. Robustness tests were conducted to assess the potential for endogeneity in our model by employing a two-stage least squares estimation (2SLS).

\section{Results}

\subsection{Descriptive statistics}

Descriptive statistics of Board Structure Index (BSI), from 2002 to 2017, are presented in Table 4.

Table 4 shows that the average BSI score is 4.80 given that 7 is the maximum score of the index. Considering annual average scores, there is an evolution in the adoption of corporate governance practices between 2002 and 2017. The average BSI score was 3.75 in 2002 and 5.86 in 2017, representing an increase of $56.27 \%$. In 2002, 50\% of SOEs scored 4 points on the index, while in 2017 their score went up to 6, out of a total of 7 .

It is noteworthy that this period comprises an evolution of corporate governance practices due to their development and recognition over the years. In the early 2000s, corporate governance discussion starts to gain attention, with the creation of the special listing segments in Bovespa and the SarbanesOxley Act in 2002, in the US. Thus, the results obtained for the initial years of the analysis corroborate the incipient development of corporate governance in the Brazilian market. Such a scenario is also confirmed by little voluntary disclosure, in IANs, of corporate governance practices adopted by firms, especially between 2002 and 2004. Even when information was available in those years, it was often generic content on management and strategy, and not specific regarding governance measures adopted.

The average BSI score can also be analyzed for each economic sector, as presented in Table 5.

The financial sector presented the highest average BSI score, in 2017, and 


\section{Table 4}

\section{Board Structure Index (BSI) descriptive statistics (2002 to 2017)}

Total number of observations (337) differs from the regression analysis observation (327) due to missing data relative to Tobin's $q$ for some firms in different years, leading to an unbalanced panel data. The number of annual observations indicates the number of firms, which varies due to IPOs in 2006 and 2013.

\begin{tabular}{llllllcc}
\hline year & obs. & mean & std. dev. & min & max & $\begin{array}{c}\text { 2nd } \\
\text { quartile }\end{array}$ & $\begin{array}{c}\text { 3rd } \\
\text { quartile }\end{array}$ \\
\hline 2002 & 20 & 3.75 & 0.9104 & 2 & 5 & 4 & 4 \\
2003 & 20 & 3.90 & 0.9680 & 2 & 6 & 4 & 4.5 \\
2004 & 20 & 3.95 & 0.8870 & 3 & 6 & 4 & 4.5 \\
2005 & 20 & 4.10 & 0.9680 & 3 & 6 & 4 & 5 \\
2006 & 21 & 4.43 & 0.9258 & 3 & 6 & 4 & 5 \\
2007 & 21 & 4.67 & 0.9660 & 3 & 6 & 5 & 5 \\
2008 & 21 & 4.62 & 0.9206 & 3 & 6 & 5 & 5 \\
2009 & 21 & 4.71 & 0.9562 & 3 & 7 & 5 & 5 \\
2010 & 21 & 4.76 & 0.8891 & 3 & 7 & 5 & 5 \\
2011 & 21 & 5.04 & 0.9207 & 3 & 7 & 5 & 6 \\
2012 & 21 & 5.10 & 0.9437 & 3 & 7 & 5 & 6 \\
2013 & 22 & 5.23 & 0.9223 & 4 & 7 & 5 & 6 \\
2014 & 22 & 5.23 & 0.9223 & 4 & 7 & 5 & 6 \\
2015 & 22 & 5.23 & 0.9726 & 3 & 7 & 5 & 6 \\
2016 & 22 & 5.41 & 0.9081 & 4 & 7 & 5 & 6 \\
2017 & 22 & 5.86 & 0.8888 & 4 & 7 & 6 & 7 \\
\hline Total & 337 & 4.80 & 1.0740 & 2 & 7 & 5 & 5 \\
\hline
\end{tabular}

it is the only period with an average BSI higher than 6, considering all sectors. Table 5 indicates the evolution of corporate governance practices regarding the board of directors for all economic sectors. The only exception is the cyclical consumption sector, with only one firm, which has not presented an evolution since 2003.

In order to identify the evolution of the structure of boards, from 2002 to 2017, the percentage of firms that scored on each attribute of the BSI was calculated. The results are presented in Table 6 .

Considering a horizontal analysis of the frequency of positive scores, results indicate that SOEs increasingly adopted all attributes, except that of question 2 - board size between 5 to 11 members - which oscillated during the period of analysis. Questions 4, 6 and 7 showed a significant increase in their adoption by SOEs over the years.

The provision in the bylaws for the participation of independent directors - attribute 4 in the BSI - was adopted by $5 \%$ of SOEs in 2002, rising to $68 \%$ in 2017 . There is an evident evolution regarding this practice in boards over the 16 years of analysis, which indicates more attention devoted to this topic recently. Directors' independence is extremely relevant for discussing corporate governance in SOEs, as the literature shows. Nonetheless, directors 
Table 5

Average annual BSI score by economic sector

\begin{tabular}{lcccc}
\hline & \multicolumn{4}{c}{ economic sector } \\
\cline { 2 - 5 } year & financial (8) & energy (8) & $\begin{array}{c}\text { water and } \\
\text { sanitation (5) }\end{array}$ & $\begin{array}{c}\text { cyclic } \\
\text { consumption (1) }\end{array}$ \\
\hline 2002 & 3.71 & 3.75 & 3.75 & 4.00 \\
2003 & 3.71 & 3.88 & 4.00 & 5.00 \\
2004 & 3.86 & 3.88 & 4.00 & 5.00 \\
2005 & 3.86 & 4.13 & 4.25 & 5.00 \\
2006 & 4.43 & 4.38 & 4.40 & 5.00 \\
2007 & 4.57 & 4.75 & 4.60 & 5.00 \\
2008 & 4.57 & 4.75 & 4.40 & 5.00 \\
2009 & 4.71 & 4.75 & 4.60 & 5.00 \\
2010 & 4.71 & 4.75 & 4.80 & 5.00 \\
2011 & 5.00 & 5.13 & 5.00 & 5.00 \\
2012 & 5.00 & 5.25 & 5.00 & 5.00 \\
2013 & 5.38 & 5.25 & 5.00 & 5.00 \\
2014 & 5.38 & 5.13 & 5.20 & 5.00 \\
2015 & 5.38 & 5.00 & 5.40 & 5.00 \\
2016 & 5.38 & 5.50 & 5.40 & 5.00 \\
2017 & 6.13 & 5.88 & 5.60 & 5.00 \\
\hline total mean & 4.74 & 4.76 & 4.71 & 4.93 \\
\hline
\end{tabular}

Number of SOEs listed in the respective economic sectors are in parentheses.

Table 6

Percentage $(\%)$ of positive scores on each question of the Board Structure Index (2002-2017)

\begin{tabular}{|c|c|c|c|c|c|c|c|c|c|c|c|c|c|c|c|c|}
\hline \multirow[b]{2}{*}{ Q } & \multicolumn{13}{|c|}{ board structure index } & \multirow[b]{2}{*}{2015} & \multirow[b]{2}{*}{2016} & \multirow[b]{2}{*}{2017} \\
\hline & 2002 & 2003 & 2004 & 2005 & 2006 & 2007 & 2008 & 2009 & 2010 & 2011 & 2012 & 2013 & 2014 & & & \\
\hline 1 & 65 & 80 & 85 & 90 & 86 & 90 & 90 & 90 & 90 & 90 & 90 & 86 & 86 & 86 & 91 & 91 \\
\hline 2 & 80 & 80 & 75 & 75 & 81 & 81 & 76 & 76 & 81 & 90 & 90 & 91 & 86 & 86 & 86 & 91 \\
\hline 3 & 90 & 90 & 90 & 90 & 90 & 95 & 95 & 95 & 95 & 95 & 95 & 95 & 91 & 91 & 95 & 95 \\
\hline 4 & 5 & 0 & 5 & 15 & 33 & 38 & 38 & 38 & 38 & 38 & 38 & 45 & 50 & 50 & 55 & 68 \\
\hline 5 & 75 & 75 & 75 & 75 & 76 & 76 & 76 & 76 & 76 & 76 & 76 & 77 & 77 & 77 & 77 & 95 \\
\hline 6 & 55 & 60 & 60 & 60 & 71 & 76 & 76 & 81 & 81 & 86 & 86 & 86 & 91 & 91 & 91 & 100 \\
\hline 7 & 5 & 5 & 5 & 5 & 5 & 10 & 10 & 14 & 14 & 29 & 33 & 36 & 36 & 36 & 41 & 41 \\
\hline
\end{tabular}


declared as independent may have indirect political connections, as argued by Shi et al. (2018). In this case, they are less susceptible to incentives to monitor managers, which negatively affects the value of SOEs under political interference. The findings also highlight that even though board independence is fundamental for corporate governance in SOEs, the practice was adopted by only $68 \%$ of boards in 2017 , which is considered a low percentage, given the importance of this attribute.

Question 6 from BSI considers whether the length of the director's mandate is up to 2 years. This practice was adopted by 55\% of SOEs in 2002 and by the entire sample in 2017. This is the only BSI attribute adopted by $100 \%$ of the Brazilian listed SOEs considered in the sample.

Question 7 - regarding the performance evaluation mechanisms of the board - is the least frequently adopted practice in 2017. It was adopted by only $5 \%$ of firms in 2002, rising to $41 \%$ in 2017 . The higher frequency of adoption of this governance practice in recent years highlights the importance of Federal Law ${ }^{0}$ 13.303/2016 (Brasil; 2016) in demanding the implementation of performance evaluation mechanisms in SOEs' boards, given that little attention had previously been directed to this governance practice.

Regarding the dependent and control variables, descriptive statistics are presented in Table 7.

Table 7 shows that SOEs obtained Tobin's $q>1$ only in 2007, 2008 and 2015 to 2017 , indicating that these firms generated value in only 5 years of the 16 -year period. By presenting $q>1$, SOEs indicate, on average, shareholder value creation, since their market value is higher than their asset replacement cost. However, the full sample mean indicates a value lower than 1 , which represents the destruction of value, by not exceeding the opportunity cost of invested capital (Assaf Neto; 2010).

Considering the performance variables, ROA and ROE, annual means indicate an improvement in firms' performance from 2002 to 2017. However, results show some oscillating values, especially from 2009 to 2015. Such oscillations in ROA and ROE can be explained by the global economic crisis, which collapsed firms' financial results, as shown by Maranhão et al. (2016) in similar results obtained for the same variables. Regarding the dummy variable of special listing in Level 2 or New Market, only 6 of 22 SOEs analyzed were listed in such segments of the B3 stock exchange by the end of 2017.

\subsection{Effects of board structure on firm value and performance}

Table 8 presents the Pearson correlation matrix. All correlation coefficients are lower than 0.8 and all variables present Variation Inflation Factors (VIF) lower than 3, which implies the absence of multicollinearity (Wooldridge; 
Table 7

\section{Dependent and control variables descriptive statistics (2002-2017)}

Tobin's $q$, return on total assets (ROA) and return on equity (ROE) are the dependent variables. Percentage of leverage (LEV), natural logarithm of firm size (SIZE) and stock liquidity (LIQ) are control variables.

\begin{tabular}{|c|c|c|c|c|c|c|c|}
\hline \multirow[t]{2}{*}{ year } & \multicolumn{7}{|c|}{ mean } \\
\hline & obs. & Tobin's $q$ & $q$ ROA & ROE & LEV & SIZE & LIQ \\
\hline 2002 & 19 & 0.570 & -0.305 & -0.339 & 66.390 & 22.473 & 0.309 \\
\hline 2003 & 19 & 0.529 & 0.420 & 4.899 & 67.633 & 22.544 & 0.280 \\
\hline 2004 & 19 & 0.535 & 2.292 & 8.508 & 67.320 & 22.602 & 0.274 \\
\hline 2005 & 18 & 0.563 & 3.330 & 12.827 & 63.400 & 22.688 & 0.253 \\
\hline 2006 & 19 & 0.644 & 3.528 & 14.976 & 55.879 & 22.751 & 0.299 \\
\hline 2007 & 20 & 1.041 & 4.542 & 13.297 & 53.833 & 22.600 & 0.261 \\
\hline 2008 & 20 & 1.033 & 6.035 & 15.727 & 52.415 & 22.729 & 0.302 \\
\hline 2009 & 21 & 0.822 & 4.618 & 14.770 & 54.791 & 22.809 & 0.264 \\
\hline 2010 & 21 & 0.817 & 5.689 & 15.658 & 53.478 & 22.925 & 0.271 \\
\hline 2011 & 21 & 0.770 & 4.095 & 12.616 & 53.553 & 23.023 & 0.271 \\
\hline 2012 & 21 & 0.875 & 3.036 & 9.592 & 54.810 & 23.111 & 0.263 \\
\hline 2013 & 22 & 0.997 & 2.721 & 9.569 & 54.743 & 23.119 & 0.304 \\
\hline 2014 & 21 & 0.953 & 3.668 & 7.372 & 55.816 & 23.235 & 0.407 \\
\hline 2015 & 22 & 1.053 & 3.225 & 7.622 & 56.961 & 23.224 & 0.362 \\
\hline 2016 & 22 & 1.070 & 3.904 & 9.276 & 55.230 & 23.267 & 0.384 \\
\hline \multirow[t]{3}{*}{2017} & 22 & 1.069 & 4.496 & 9.604 & 56.125 & 23.320 & 0.330 \\
\hline & \multicolumn{7}{|c|}{ full sample } \\
\hline & obs. & Tobin's $q$ & $q$ ROA & ROE & LEV & SIZE & LIQ \\
\hline mean & 327 & 0.842 & 3.496 & 10.391 & 57.438 & 22.916 & 0.303 \\
\hline std. dev. & & 0.922 & 7.442 & 17.635 & 28.954 & 1.9040 & 0.666 \\
\hline minimum & & 0.121 & -16.555 & -62.126 & 1.236 & 19.089 & 0 \\
\hline maximum & & 6.279 & 33.133 & 51.952 & 95.485 & 27.929 & 2.724 \\
\hline 3rd quartile & & 0.842 & 5.349 & 20.337 & 89.131 & 23.701 & 0.144 \\
\hline
\end{tabular}

2011).

Table 9 presents the multiple regression results, estimated by fixed and random effects, to investigate the relation between board structure, performance and firm value of listed Brazilian SOEs.

Table 9 results indicate a significant positive relation between Tobin's $q$ and the Board Structure Index (BSI), which does not allow rejecting $\mathrm{H}_{1}$. Therefore, the one-score increase in the BSI - represented by the additional adoption of a board-related corporate governance practice - is associated with a 0.086 increase in firm value of Brazilian listed SOEs. This result is expected, corroborating recent studies such as that of Black et al. (2020). They find that board structure index is statistically significant when predicting Tobin's $q$ in Brazil, and this result is driven mostly by board independence. As discussed earlier, board independence is highly relevant for SOEs, since members nominated by the government can be manipulated to achieve politi- 
Table 8

Correlation matrix

\begin{tabular}{lrrrrrrrr}
\hline & BSI & Tobin's $q$ & ROE & ROA & LEV & SIZE & LIQ & N2NM \\
\hline BSI & 1.0000 & & & & & & & \\
Tobin's $q$ & $\mathbf{0 . 2 5 3 5}$ & 1.0000 & & & & & & \\
ROE & $\mathbf{0 . 1 2 4 2}$ & $\mathbf{0 . 1 3 2 5}$ & 1.0000 & & & & & \\
ROA & $\mathbf{0 . 1 8 5 2}$ & $\mathbf{0 . 3 9 3 3}$ & $\mathbf{0 . 6 7 5 4}$ & 1.0000 & & & \\
LEV & -0.0320 & $-\mathbf{0 . 1 6 3 3}$ & 0.0605 & $-\mathbf{0 . 4 0 0 1}$ & 1.0000 & & \\
SIZE & $\mathbf{0 . 4 6 0 1}$ & 0.0541 & $\mathbf{0 . 2 0 5 9}$ & 0.0839 & $\mathbf{0 . 1 3 6 1}$ & 1.0000 & & \\
LIQ & $\mathbf{0 . 5 0 7 6}$ & $\mathbf{0 . 3 2 9 1}$ & -0.1528 & $\mathbf{0 . 1 6 0 9}$ & 0.0102 & 0.7075 & 1.0000 & \\
N2NM & $\mathbf{0 . 4 6 4 8}$ & $\mathbf{0 . 2 6 6 7}$ & $\mathbf{0 . 1 2 0 4}$ & $\mathbf{0 . 2 1 2 4}$ & $-\mathbf{0 . 1 3 2 7}$ & 0.2000 & 0.3148 & 1.0000 \\
\hline
\end{tabular}

Boldface indicates statistical significance at $5 \%$ level or better.

Table 9

Fixed and random effects regression results of the relation between board structure and firm value and performance

Tobin's $q$, return on total assets (ROA) and return on equity (ROE) are the dependent variables. Percentage of leverage (LEV), natural logarithm of firm size (SIZE), special segment listing (N2NM) and stock liquidity (LIQ) are used as control variables. Return on assets (ROA) is included as a control variable for regression on Tobin's $q$. Industry dummies are included in the random effects (RE) estimations and year dummies for fixed effects (FE) estimations. Variable N2NM drops out in FE estimation. $t$-statistics are in parentheses. *, **, *** indicate statistical significance to $10 \%, 5 \%$ and $1 \%$, respectively. Stata's option robust was used for the estimations to correct for heteroskedasticity.

\begin{tabular}{|c|c|c|c|}
\hline model & Tobin's $q$ & ROA & ROE \\
\hline specification & $\mathrm{RE}$ & RE & $\mathrm{FE}$ \\
\hline BSI & $\begin{array}{c}\mathbf{0 . 0 8 6 0}^{* * *} \\
(2.22)\end{array}$ & $\begin{array}{c}\text { 1.0432**** } \\
(3.64)\end{array}$ & $\begin{array}{c}\text { 3.0718*** }^{* * 11)} \\
(2.11)\end{array}$ \\
\hline ROA & $\begin{array}{c}0.0087 \\
(1.55)\end{array}$ & $\begin{array}{l}0 \\
(.)\end{array}$ & $\begin{array}{l}0 \\
\text { (.) }\end{array}$ \\
\hline LEV & $\begin{array}{c}0.0019 \\
(0.83)\end{array}$ & $\begin{array}{c}-\mathbf{0 . 1 8 3 9} * * * \\
(-3.48)\end{array}$ & $\begin{array}{c}-0.2468 \\
(-1.58)\end{array}$ \\
\hline SIZE & $\begin{array}{c}-\mathbf{0 . 1 0 7 3}^{*} \\
(-1.66)\end{array}$ & $\begin{array}{l}-1.0357 \\
(-1.34)\end{array}$ & $\begin{array}{r}-2.1849 \\
(-0.52)\end{array}$ \\
\hline LIQ & $\begin{array}{c}\mathbf{0 . 5 5 4 2} * * * \\
(3.12)\end{array}$ & $\begin{array}{l}1.5190 \\
(1.10)\end{array}$ & $\begin{array}{c}0.6414 \\
(0.22)\end{array}$ \\
\hline $\mathrm{N} 2 \mathrm{NM}$ & $\begin{array}{c}0.2928 \\
(1.61)\end{array}$ & $\begin{array}{l}0.2627 \\
(0.22)\end{array}$ & $\begin{array}{l}0 \\
(.)\end{array}$ \\
\hline Hausman test $\left(\operatorname{Pr}>\chi^{2}\right)$ & 0.1087 & 0.3207 & 0.0025 \\
\hline $\mathrm{R}^{2}$ (overall) & 0.2142 & 0.3299 & 0.0017 \\
\hline $\mathrm{R}^{2}$ (within) & 0.1170 & 0.1920 & 0.1756 \\
\hline $\mathrm{R}^{2}$ (between) & 0.4318 & 0.6890 & 0.0660 \\
\hline number of groups & 22 & 22 & 22 \\
\hline observations & 327 & 327 & 327 \\
\hline
\end{tabular}


cal interests seldom aligned with firms' business interests, and thus impacting their outcomes (Apriliyanti and Randøy; 2019). Moreover, our results corroborate findings from other studies involving board attributes and firm value, also proxied by Tobin's $q$, such as Fauver et al. (2017), Kao et al. (2019) and Bhat et al. (2018) for a sample of SOEs in Pakistan.

Considering the control variables in the model with Tobin's $q$ as the dependent variable, stock liquidity (LIQ) presents a positive relation with Tobin's $q$, at the $1 \%$ significance level. This result corroborates the argument of Lameira et al. (2007) about a higher stock circulation and value, due to higher stock liquidity. Firm size presents a negative relation to Tobin's $q$, which is consistent with the results from Kao et al. (2019) for the same variables.

The return on equity (ROE) performance variable has a positive and significant relation, at the level of $1 \%$, with the board structure index (BSI), which does not allow rejecting $\mathrm{H}_{2}$. Thus, the one-score increase in the BSI results in a 1.0432 increase in ROE of Brazilian listed SOEs. The positive relation between board structure and ROE follows other studies involving corporate governance attributes of the board, such as Liu et al. (2015) - for the specific context of SOEs - and Kao et al. (2019). Considering the return on assets (ROA) performance variable, it has a positive and significant relation, at the level of 5\%, with the board structure index (BSI), which does not allow rejecting $\mathrm{H}_{2}$. ROA indicator increases by 3.0718 with a one-score increment in BSI for Brazilian listed SOEs. This finding is consistent with Paiva et al. (2015) - who also find a significant positive relation between ROA and a board structure index for Brazil - in addition to Liu et al. (2015) and Kao et al. (2019).

The positive relation between board structure and performance can be explained considering that an improved board can exercise better monitoring, according to agency theory (Fama and Jensen; 1983). In this sense, following Kao et al. (2019), our results indicate that improved board structure - considering aspects such as independence and no duality of positions between CEO and board chairman - is positively related to Brazilian listed SOEs' performance, since it helps to alleviate agency costs. Since SOEs face more severe agency conflicts in the principal-principal agency theory perspective (Chen et al.; 2019), the positive relation of board independence and performance is even more consequential for firms in this context, as explained by Liu et al. (2015). However, our findings contrast with Black et al. (2020) who find no significant relation between board structure and ROA for Brazil, although these authors do not focus on SOEs. In this case, Black et al. (2020) conclude that improvements in corporate governance practices do not appear to improve the magnitude of cash flows, but the price that investors would pay 
for them.

Regarding the control variables for ROA and ROE models, leverage (LEV) presents statistical significance in its negative relation with ROA, corroborating results obtained by Paiva et al. (2015). This negative relation can be explained considering the results of Fama and French (1998) that contradict the hypothesis that debt is associated with net tax benefits. Therefore, this can be reflected in a decrease in net profits and, consequently, in ROA, holding total assets constant. In addition, the agency conflicts between bondholders and stockholders that arise in the presence of risky debt is a rationale for limiting borrowing (Myers; 1977), and as suggested by Fama and French (1998), such agency conflicts can explain the negative influence of leverage on profitability.

\subsection{Robustness tests}

In governance-to-value studies (Ararat et al.; 2017) the performance and firm value proxies may influence corporate governance (Black et al.; 2020). Thus, corporate governance variables may be considered as endogenous. In order to initially assess the potential endogeneity in our model, we follow Black et al. (2020) and run regressions employing the lagged outcome variables (Tobin's $q$, ROA and ROE) as predictors of board structure index (BSI). The results are presented in Table 10 .

There is evidence that these variables do not significantly predict BSI, except for lagged ROA in FE estimation. Therefore, we expect potential reverse causation to be limited in our sample, in accordance with Black et al. (2020) who identify and highlight the limited concern of reverse causation in emerging markets. Although lagged ROA is significant in predicting BSI in FE estimation, panel data regressions may be biased due to endogeneity. Thus, we employ two-stage least squares (2SLS) as a robust regression estimation to address this issue.

In the 2SLS estimation, we tested our model by instrumenting the potential endogenous regressor BSI, following Wooldridge (2011). The one-yearlagged value of the endogenous governance variable - BSI - is used as the potential instrumental variable (IV) since it is correlated with BSI but not with the error terms, following Kao et al. (2019). However, Kao et al. (2019) explain that 2SLS may not be a better alternative to panel data design in providing adequate estimates, due to the difficulty in finding appropriate instruments, both in terms of theory and empirical adequacy. Black et al. (2020) also highlight the unconvincing aspect of these instruments and employ panel data design with fixed and random effects estimations. Table 11 presents the results of the 2 SLS estimation and the specification test for the instruments. 
Table 10

\section{Lagged Tobin's $q$, ROE and ROA as predictors of Board Structure Index}

One-year-lagged values of Tobin's $q$, return on total assets (ROA) and return on equity (ROE) are the predictor variables and Board Structure Index is the outcome variable. The models are estimated by fixed effects (FE) and ordinary least squares (OLS) with year dummies included. Variable N2NM drops out in FE estimation. $t$-statistics are in parentheses. *, ** indicate statistical significance to $5 \%$ and $1 \%$, respectively. Stata's option robust was used for the estimations to correct for heteroskedasticity.

\begin{tabular}{|c|c|c|c|c|c|c|}
\hline \multirow{2}{*}{$\frac{\text { model }}{\text { specification }}$} & \multicolumn{6}{|c|}{ board structure index } \\
\hline & FE & OLS & FE & OLS & $\mathrm{FE}$ & OLS \\
\hline L.Tobin's $q$ & $\begin{array}{c}0.0345 \\
(0.42)\end{array}$ & $\begin{array}{l}-0.0737 \\
(-1.45)\end{array}$ & & & & \\
\hline L.ROA & & & $\begin{array}{c}0.0173^{*} \\
(2.55)\end{array}$ & $\begin{array}{c}0.0049 \\
(0.80)\end{array}$ & & \\
\hline L.ROE & & & & & $\begin{array}{c}0.0073 \\
(2.06)\end{array}$ & $\begin{array}{c}0.0002 \\
(0.07)\end{array}$ \\
\hline LEV & $\begin{array}{c}0.0027 \\
(0.94)\end{array}$ & $\begin{array}{l}0.0017 \\
(1.24)\end{array}$ & $\begin{array}{c}0.0061 \\
(1.08)\end{array}$ & $\begin{array}{c}0.0024 \\
(1.60)\end{array}$ & $\begin{array}{c}0.0049 \\
(0.93)\end{array}$ & $\begin{array}{c}0.0019 \\
(1.37)\end{array}$ \\
\hline SIZE & $\begin{array}{l}-0.1205 \\
(-1.12)\end{array}$ & $\begin{array}{c}0.0370 \\
(1.17)\end{array}$ & $\begin{array}{l}-0.1375 \\
(-0,65)\end{array}$ & $\begin{array}{l}0.0497 \\
(1.63)\end{array}$ & $\begin{array}{c}-0.1196 \\
(-0.59)\end{array}$ & $\begin{array}{c}0.0498 \\
(1.62)\end{array}$ \\
\hline LIQ & $\begin{array}{c}0.0913 \\
(0.56)\end{array}$ & $\begin{array}{c}\mathbf{0 . 6 1 3 1} * * * \\
(6.36)\end{array}$ & $\begin{array}{l}0.1327 \\
(0.52)\end{array}$ & $\begin{array}{c}\mathbf{0 . 5 4 8 0}^{* *} * \\
(6.17)\end{array}$ & $\begin{array}{l}0.1186 \\
(0.46)\end{array}$ & $\begin{array}{c}\mathbf{0 . 5 5 5 3} * * \\
(6.28)\end{array}$ \\
\hline N2NM & $\begin{array}{l}0 \\
(.)\end{array}$ & $\begin{array}{c}\mathbf{0 . 7 4 5 0} * * * * \\
(7.11)\end{array}$ & $\begin{array}{l}0 \\
(.)\end{array}$ & $\begin{array}{c}\mathbf{0 . 7 3 1 6} \text { *** } \\
(6.88)\end{array}$ & $\begin{array}{l}0 \\
(.)\end{array}$ & $\begin{array}{c}\mathbf{0 . 7 3 8 7} * * \\
(6.94)\end{array}$ \\
\hline $\mathrm{R}^{2}$ (overall) & 0.1467 & 0.6044 & 0.1616 & 0.6023 & 0.1755 & 0.6014 \\
\hline $\mathrm{R}^{2}$ (within) & 0.5666 & & 0.5785 & & 0.5824 & \\
\hline $\mathrm{R}^{2}$ (between) & 0.0032 & & 0.0263 & & 0.0203 & \\
\hline observations & 302 & 302 & 302 & 302 & 302 & 302 \\
\hline
\end{tabular}

Results from Tobin's $q$ model indicate a positive and significant coefficient for BSI, consistent with the results from panel data with RE estimation. The control variables coefficients' signs are consistent with RE estimation. ROA and N2NM coefficients become significant in the 2SLS estimation, in addition to SIZE and LIQ.

Considering ROA and ROE as the outcome variables, results indicate that BSI coefficients are not significant, while there is a positive relation to ROA and a negative relation to ROE. Control variables' coefficients from the ROA model are consistent with RE estimation, except for SIZE, and LIQ becomes significant in 2SLS estimation. In the ROE model, BSI has a negative sign while LEV, SIZE and N2NM coefficients become positive and significant in 2SLS estimation.

Post estimation tests were conducted to assess the appropriateness of the IV and the potential endogeneity of BSI as a regressor in our just-identified model. First, we investigate if the IV is relevant by addressing the problem of weak instruments, based on the first-stage F-statistic for the joint significance of the instruments (Cameron and Triverdi; 2009). The first-stage F-statistics for all models in Table 11 greatly exceed the critical values provided by Stock 


\section{Table 11}

\section{SLS regression results for the relation between board structure and firm value and performance.}

\begin{tabular}{|c|c|c|c|}
\hline model & Tobin's $q$ & ROA & ROE \\
\hline L.BSI & $\begin{array}{c}\mathbf{0 . 0 7 5 3 *} \\
(1.66)\end{array}$ & $\begin{array}{c}\mathbf{0 . 1 1 1 3} \\
(0.19)\end{array}$ & $\begin{array}{l}-\mathbf{2 . 2 4 6 3} \\
(-1.58)\end{array}$ \\
\hline ROA & $\begin{array}{c}\mathbf{0 . 0 3 6 9}^{* * *} \\
(3.17)\end{array}$ & & \\
\hline LEV & $\begin{array}{c}0.0010 \\
(0.79)\end{array}$ & $\begin{array}{c}-\mathbf{0 . 1 0 1 0} * * * * \\
(-7.33)\end{array}$ & $\begin{array}{c}\mathbf{0 . 0 7 1 7} * * \\
(2.05)\end{array}$ \\
\hline SIZE & $\begin{array}{c}-\mathbf{0 . 1 8 5 0} * * * \\
(-4.24)\end{array}$ & $\begin{array}{c}0.0892 \\
(0.21)\end{array}$ & $\begin{array}{c}\mathbf{2 . 0 7 0 7 *} \\
(1.88)\end{array}$ \\
\hline LIQ & $\begin{array}{c}\mathbf{0 . 7 0 7 0} \text { **** } \\
(5.77)\end{array}$ & $\begin{array}{c}\mathbf{1 . 0 6 2 8} \\
(0.92)\end{array}$ & $\begin{array}{c}0.4503 \\
(0.18)\end{array}$ \\
\hline $\mathrm{N} 2 \mathrm{NM}$ & $\begin{array}{c}\text { 0.1452* } \\
(1.75)\end{array}$ & $\begin{array}{c}\text { 1.9238* } \\
(1.82)\end{array}$ & $\begin{array}{c}\mathbf{6 . 3 4 6 4} * * * * \\
(2.75)\end{array}$ \\
\hline $\mathrm{R}^{2}$ & 0.3113 & 0.1999 & 0.0752 \\
\hline Durbin-Wu-Hausman $F$ & $5.29921 *$ & 0.0974 & 2.1305 \\
\hline first-stage $F$-statistic & 444.309 & 447.984 & 447.984 \\
\hline observations & 302 & 302 & 302 \\
\hline
\end{tabular}

and Yogo (2005), for one endogenous regressor and one instrumental variable. This suggests that one-year-lagged values of BSI are relevant as IV and the weak instrument problem is not a concern.

The potential endogeneity of BSI was investigated with the Durbin-WuHausman test, with the null hypothesis that the instrumented regressor is exogenous (Cameron and Triverdi; 2009). Table 11 results indicate that only the F-statistic of Tobin's $q$ model is significant at the limit of $10 \%$ level $(\mathrm{F}=$ 5.29921, $\mathrm{p}=0.0652$ ). Therefore, BSI can be considered endogenous when predicting Tobin's $q$ and 2SLS is more appropriate than panel data regressions with RE estimation. However, both estimations present similar positive coefficients for BSI ( $b_{1}=0,0860$ and $b_{1}=0.0753$ for RE and 2SLS, respectively). ROA and ROE models present non-significant F-statistics for the Durbin-WuHausman test of endogeneity $(\mathrm{F}=0.0974, \mathrm{p}=0.7552$; and $\mathrm{F}=2.1305, \mathrm{p}=$ 0.1455 , for ROA and ROE, respectively). Therefore, the null hypothesis that the regressor BSI is exogenous cannot be rejected, which implies that previous panel data regressions with RE and FE estimations are not biased, and thus are appropriate for ROA and ROE models, as employed by Black et al. (2020).

Additional robustness tests were conducted to assess the sensitivity of the regression results presented in Table 9. Since two performance measures 
Table 12

\section{Regression results with natural logarithm of market value as an alternative proxy for firm value}

\begin{tabular}{|c|c|c|c|c|c|}
\hline \multicolumn{6}{|c|}{$\begin{array}{l}\text { Natural logarithm of market v } \\
\text { proxy for firm value. Outliers } \\
\text { estimated by random effects a } \\
\text { year and used as instrumental } \\
\text { significance to } 10 \%, 5 \% \text {, and } \\
\text { correct for heteroskedasticity. }\end{array}$} \\
\hline model & $\begin{array}{c}\text { A } \\
\text { Tobin's } q \\
\text { RE }\end{array}$ & $\begin{array}{c}\mathrm{B} \\
\text { Tobin's } q \\
\text { RE }\end{array}$ & $\begin{array}{c}C \\
\ln (\mathrm{mv}) \\
\mathrm{RE}\end{array}$ & $\begin{array}{c}D \\
\ln (\mathrm{mv}) \\
\mathrm{RE}\end{array}$ & $\begin{array}{c}E \\
\ln (\mathrm{mv}) \\
2 \mathrm{SLS}\end{array}$ \\
\hline BSI & $\begin{array}{c}\mathbf{0 . 0 9 0 4} * * \\
(2.27)\end{array}$ & $\begin{array}{c}\mathbf{0 . 0 8 6 0}^{* * *} \\
(2.22)\end{array}$ & $\begin{array}{c}\mathbf{0 . 1 5 3 0} * \\
(1.79)\end{array}$ & $\begin{array}{c}\mathbf{0 . 1 5 3 3} * \\
(1.79)\end{array}$ & $\begin{array}{c}0.0407 \\
(0.74)\end{array}$ \\
\hline ROA & $\begin{array}{c}0.0070 \\
(1.13)\end{array}$ & $\begin{array}{c}0.0087 \\
(1.55)\end{array}$ & $\begin{array}{c}\mathbf{0 . 0 2 1 3} * * \\
(2.02)\end{array}$ & $\begin{array}{c}\mathbf{0 . 0 2 6 7} * * * \\
(3.09)\end{array}$ & $\begin{array}{c}0.0423 * * * \\
(5.46)\end{array}$ \\
\hline LEV & $\begin{array}{c}0.0013 \\
(0.52)\end{array}$ & $\begin{array}{c}0.0019 \\
(0.83)\end{array}$ & $\begin{array}{c}-\mathbf{0 . 0 1 4 3} * * * \\
(-2.79)\end{array}$ & $\begin{array}{c}-\mathbf{0 . 0 1 3 1} * * * \\
(-2.93)\end{array}$ & $\begin{array}{c}-0.0190 * * * \\
(-14.08)\end{array}$ \\
\hline SIZE & $\begin{array}{l}-0.1190 \\
(-1.64)\end{array}$ & $\begin{array}{c}-\mathbf{0 . 1 0 7 3} * \\
(-1.66)\end{array}$ & $\begin{array}{c}\mathbf{0 . 7 2 8 2} * * * * \\
(6.83)\end{array}$ & $\begin{array}{c}\mathbf{0 . 7 1 7 3} * * * \\
(6.83)\end{array}$ & $\begin{array}{c}0.8541 * * * \\
(20.60)\end{array}$ \\
\hline LIQ & $\begin{array}{c}\mathbf{0 . 5 4 3 0} * * * \\
(2.60)\end{array}$ & $\begin{array}{c}\mathbf{0 . 5 5 4 2} * * * \\
(3.12)\end{array}$ & $\begin{array}{c}0.2394 \\
(1.29)\end{array}$ & $\begin{array}{c}0.2913 \\
(1.40)\end{array}$ & $\begin{array}{l}0.3565 * * * \\
(3.88)\end{array}$ \\
\hline $\mathrm{N} 2 \mathrm{NM}$ & $\begin{array}{c}\mathbf{0 . 3 2 5 1}^{*} \\
(1.75)\end{array}$ & $\begin{array}{l}0.2928 \\
(1.61)\end{array}$ & $\begin{array}{l}0.1495 \\
(0.63)\end{array}$ & $\begin{array}{l}0.1191 \\
(0.52)\end{array}$ & $\begin{array}{c}-0.00156 \\
(0.52)\end{array}$ \\
\hline $\begin{array}{l}\mathrm{R}^{2} \text { (overall) } \\
\text { observations }\end{array}$ & $\begin{array}{c}0.2048 \\
327\end{array}$ & $\begin{array}{c}0.2142 \\
327\end{array}$ & $\begin{array}{c}0.8597 \\
327\end{array}$ & $\begin{array}{c}0.8640 \\
327\end{array}$ & $\begin{array}{c}0.8741 \\
302\end{array}$ \\
\hline
\end{tabular}

were used as outcome variables and only one for firm value, we considered a different proxy for firm value to check the robustness of the results with the regression of Tobin's $q$. Table 12 presents the results for robustness checks for board structure and firm value relation, using the natural logarithm of market value (market value of equity + book value of debt) as a proxy for Tobin's $q$, following Black et al. (2020). The robustness checks undertaken follow Ararat et al. (2017) and are reported in Table 12.

In Table 12, Model A presents the results of the regression of Tobin's $q$ as the outcome variable without treating outliers. Model B replicates the results with Tobin's $q$ as the outcome variable and outliers winsorized at 1/99\%. The results with $\ln$ (market value) as a proxy for firm value are presented in Models C, without treating outliers, and D with outliers winsorized at 1/99\% level. The models considering market value as a proxy for firm value present positive and significant coefficients for Board Structure Index, corroborating the results for Tobin's $q$ as the outcome variable. Besides, control variables ROA, leverage, and firm size become statistically significant when considering market value. The results are consistent with Black et al. (2020) who find similar results for the relation of board structure indices to market value and Tobin's $q$ for their Brazilian sample. 


\section{Conclusion}

This study investigated the relation between the structure of the board of directors of Brazilian listed SOEs and their financial performance and firm value. We are not aware of previous studies that investigated such relation considering Brazilian listed SOEs. In the context of SOEs, the need to improve the structure of the board of directors, following corporate governance best practices, becomes even more relevant to minimize political interference. Considering listed SOEs, in the presence of other private investors, effective manager monitoring is essential to assure the return on the invested capital, in addition to legitimate the firm in the capital markets, to guarantee access to resources and organizational goal achievement.

It is expected that adopting corporate governance best practices provides the board with a structure that assures its monitoring role, reducing agency conflicts. Thus, this study verified a significant positive relation between Brazilian listed SOEs' board structure, financial performance and firm value. Firms that adopt corporate governance best practices for the board exhibit better performance and higher firm value, because agency conflicts are minimized due to the efficient functioning of the board. The presence of independent board members and the absence of seats reserved on the board for members of the public administration, in addition to other governance practices, can minimize political interference surrounding SOEs. Therefore, promoting governance practices that provide better decision making by the board is of great importance to ensure the sustainable continuity of business in listed SOEs.

In addition to investigating the relation between board structure, performance and firm value in SOEs, this study shows an evolution of corporate governance practices adopted by Brazilian listed SOEs' boards from 2002 to 2017. However, although recent data indicate a high adoption of the practices contained in the BSI by the SOEs, there is still room for improvement. In 2017, the least-adopted governance practices were related to the provision for independent board members by the bylaws and the existence of board performance evaluation mechanisms. These issues were recently considered by Federal Law n ${ }^{0} 13.303 / 2016$, with mandatory implementation by 2018 . The findings indicate that in 2017 , most firms were not in compliance with the new legal requirements, despite empirical evidence that improving corporate governance practices by boards of directors is related to higher performance and firm value in SOEs. This emphasizes the importance of the institutional environment in stimulating SOEs to comply with such governance practices in Brazil. 
In view of these findings, the present empirical study contributes, in organizational terms, to highlighting the importance of promoting corporate governance best practices in boards of directors, not only as a factor of legitimacy but as an action to promote higher performance and firm value. Such action is required, considering that listed SOEs have a major impact on society and must reconcile their social objectives with the interests of other private shareholders. This study also adds to the literature on corporate governance in SOEs, which is still limited, given the many aspects that can be explored. Thus, future studies are suggested to investigate which practices considered in the BSI are most relevant to explain variations in performance of Brazilian SOEs, also considering different aspects of the institutional environment.

\section{Acknowledgments}

This study was financed in part by the Coordenação de Aperfeiçoamento de Pessoal de Nível Superior - Brasil (CAPES) - Finance Code 001.

\section{References}

Adams, R., Hermalin, B. and Weisbach, M. (2010). The role of boards of directors in corporate governance: A conceptual framework and survey, Journal of Economic Literature 48(1): 58-107.

Apriliyanti, I. D. and Randøy, T. (2019). Between politics and business: Boardroom decision making in state-owned Indonesian enterprises, Corporate Governance: An International Review 27(3): 166-185.

Ararat, M., Black, B. S. and Yurtoglu, B. B. (2017). The effect of corporate governance on firm value and profitability: Time-series evidence from Turkey, Emerging Markets Review 30: 113-132.

Assaf Neto, A. (2010). Finanças Corporativas e Valor, Atlas, São Paulo.

Assunção, R. R., De Luca, M. M. M. and Vasconcelos, A. (2017). Complexidade e governança corporativa: Uma análise das empresas listadas na BM\&FBOVESPA, Revista de Contabilidade \& Finanças 28(74): 213-228.

B3 (2017). Regimento do Programa Destaque em Governança de Estatais.

URL: http://www.bmfbovespa.com.br/pt_br/listagem/acoes/ governanca-de-estatais/

Berk, J. and DeMarzo, P. (2017). Corporate Finance: The Core, Pearson, Harlow. 
Bhat, K. U., Chen, Y., Jebran, K. and Bhutto, A. (2018). Corporate governance and firm value: A comparative analysis of state and non-state owned companies in the context of Pakistan, Corporate Governance: The International Journal of Business in Society 18(6): 1196-1206.

Black, B. S., de Carvalho, A. G., Khanna, V., Kim, W. and Yurtoglu, B. (2020). Which aspects of corporate governance do and do not matter in emerging markets, Journal of Law, Finance, and Accounting 5(1): 137177.

Brasil (2016). Lei n. 13.303, de 30 de junho de 2016. Dispõe sobre o estatuto jurídico da empresa pública, da sociedade de economia mista e de suas subsidiárias, no âmbito da União, dos Estados, do Distrito Federal e dos Municípios. Diário Oficial da União. Brasília, DF, 01 jul. 2016. Seção 1. Access: 27/10/17.

URL: http://www . camara.leg.br/

Cameron, A. C. and Triverdi, P. K. (2009). Microeconometrics Using Stata, Stata Press, College Station.

Chen, V. A., Musacchio, A. and Li, S. (2019). A principals-principals perspective of hybrid leviathans: Cross-border acquisitions by state-owned MNEs, Journal of Management 45(7): 2751-2778.

Chung, K. H. and Pruitt, S. W. (1994). A simple approximation of Tobin's q, Financial Management 23(3): 70-74.

Fama, E. F. and French, K. R. (2002). The equity premium, Journal of Finance 57(2): 637-659.

Fama, E. and French, K. R. (1998). Taxes, financing decisions, and firm value, Journal of Finance 53(3): 819-843.

Fama, E. and Jensen, M. C. (1983). Separation of ownership and control, Journal of Law and Economics 26(2): 301-325.

Famá, R. and Barros, L. A. B. d. C. (2000). Q de Tobin e seu uso em finanças: Aspectos metodológicos e conceituais, Caderno de Pesquisas em Administração 7(4): 27-43.

Fauver, L., Hung, M., Li, X. and Taboada, A. (2017). Board reforms and firm value: Worldwide evidence, Journal of Financial Economics 125(1): 120142. 
Gitman, L. J. (2004). Princípios de Administração Financeira, Pearson, São Paulo.

Hermalin, B. and Weisbach, M. (1988). The determinants of board composition, RAND Journal of Economics 19(4): 589-606.

IBGC (2015). Código das Melhores Práticas de Governança Corporativa, 5 edn, IBGC, São Paulo.

IBGC (2017). Governança Corporativa em Empresas Estatais Listadas no Brasil, IBGC, São Paulo.

Ibhagui, O. W. and Olokoyo, F. O. (2018). Leverage and firm performance: New evidence on the role of firm size, North American Journal of Economics and Finance 45: 57-82.

Kao, M. F., Hodgkinson, L. and Jaafar, A. (2019). Ownership structure, board of directorsand firm performance: Evidence from Taiwan, Corporate Governance: The International Journal of Business in Society 19(1): 189-216.

Khongmalai, O. and Distanont, A. (2017). Corporate governance model in Thai state-owned enterprises: Structural equation modelling approach, Corporate Governance: The International Journal of Business in Society 17(4): 613-628.

Klapper, L. F. and Love, I. (2004). Corporate governance, investor protection, and performance in emerging markets, Journal of Corporate Finance 58(12): 703-728.

Lameira, V., Ness Junior, W. L. and Macedo-Soares, T. (2007). Governança corporativa: Impactos no valor das companhias abertas brasileiras, Revista de Administração-RAUSP 42(1): 64-73.

Lazzarini, S. G. and Musacchio, A. (2018). State ownership reinvented? Explaining performance differences between state-owned and private firms, Corporate Governance: An International Review 26(4): 255-272.

Liu, Y., Miletkov, M. K., Wei, Z. and Yang, T. (2015). Board independence and firm performance in China, Journal of Corporate Finance 30: 223244.

Maranhão, F. S., Fonseca, M. W. and Frega, J. R. (2016). Governança corporativa e desempenho das empresas diante da crise econômica global de 2008: Uma análise de dados em painel, Revista de Administração da UFSM 9(2): 293-311. 
Mathew, S., Ibrahim, S. and Archbold, S. (2016). Boards attributes that increase firm risk - evidence from the UK, Corporate Governance: The International Journal of Business in Society 16(2): 233-258.

Mbo, M. and Adjasi, C. (2017). Drivers of organizational performance in state owned enterprises, International Journal of Productivity and Performance Management 66(3): 405-423.

Menozzi, A., Urtiaga, M. G. and Vannoni, D. (2012). Board composition, political connections, and performance in state-owned enterprises, Industrial and Corporate Change 21(3): 671-698.

Modigliani, F. and Miller, M. H. (1958). The cost of capital, corporation finance and the theory of investment, The American Economic Review 48(3): 261-297.

Modigliani, F. and Miller, M. H. (1963). Corporate income taxes and the cost of capital: A correction, The American Economic Review 53(3): 433-443.

Musacchio, A., Lazzarini, S. G. and Aguilera, R. V. (2015). New varieties of state capitalism: Strategic and governance implications, Academy of Management Perspectives 29(1): 115-131.

Myers, S. C. (1977). Determinants of corporate borrowing, Journal of Financial Economics 5(2): 147-175.

OECD (2015). OECD Guidelines on Corporate-Governance of State-Owned Enterprises, 2 edn, OECD Publishing, Paris.

Paiva, J. F. M., Oliveira, N. A. and Peixoto, F. M. (2015). A relação entre conselho de administração, desempenho, valor e risco no mercado brasileiro de ações, Revista de Educação e Pesquisa em Contabilidade 9(1): 25-44.

SEST (2018). Indicador de Governança IG-SEST - Regulamento. Acess: $12 / 11 / 2018$.

URL:

http://editor.planejamento.gov .

br/assuntos/empresas-estatais/igsest/ regulamento-ig-sest-3o-ciclo-versao-final.pdf/view

Shawtari, F., Mohamad, M., Rashid, H. and Ayedh, A. (2017). Board characteristics and real performance in Malaysian state-owned enterprises (SOEs), International Journal of Productivity and Performance Management 66(8): 1064-1086. 
Shi, H., Xu, H. and Zhang, X. (2018). Do politically connected independent directors create or destroy value?, Journal of Business Research 83: 82-96.

Shleifer, A. and Vishny, R. W. (1994). Politicians and firms, Quarterly Journal of Economics 109(4): 995-1025.

Shleifer, A. and Vishny, R. W. (1997). A survey of corporate governance, Journal of Finance 52(2): 738-783.

Silva, A. L. C. and Leal, R. P. C. (2005). Corporate governance index, firm valuation and performance in Brazil, Revista Brasileira de Finanças 3(1): 1-18.

Silveira, A. D. M., Barros, L. A. B. C. and Famá, R. (2005). Atributos corporativos, qualidade da governança corporativa e valor das companhias abertas no Brasil, Revista Brasileira de Finanças 4(1): 1-30.

Simpson, S. N. Y. (2014). Boards and governance of state-owned enterprises, Corporate Governance 14(2): 238-251.

Stock, J. H. and Yogo, M. (2005). Testing for weak instruments in linear IV regression, in D. W. K. Andrews and J. H. Stock (eds), Identification and Inference for Econometric Models: Essays in Honor of Thomas Rothenberg, Cambridge University Press, Cambridge.

Thompson, R. M., Alleyne, P. and Charles-Soverall, W. (2019). Exploring governance issues among boards of directors within state-owned enterprises in Barbados, International Journal of Public Sector Management 32(3): 264-281.

Tong, S., Junarsin, E. and Li, C. (2015). A comparative study of Chinese SOE firm's boards and private firm's boards, Annals of Economics and Finance 16(2): 291-314.

Vilhena, F. A. C. and Camargos, M. A. (2015). Governança corporativa, criação de valor e desempenho econômico-financeiro: Evidências do mercado brasileiro com dados em painel, 2005-2011, REGE - Revista de Gestão 22(1): 77-96.

Wooldridge, J. M. (2011). Introdução à Econometria, 5 edn, Cengage Learning, São Paulo. 